\title{
Phytochemistry and method preparation of some medicinal plants used to treat asthma-review
}

\begin{abstract}
Asthma is one of the most common chronic diseases in the present day in which its incidence and severity are increasing. It is highly prevalent global disease; affecting approximately 300 million individuals worldwide. Different medicinal plants have been discovered and used in traditional medicine practices for the treatment of asthma in different part of the world since prehistoric times. The aim of this review article is to explore and compile the ethno medicinal uses, phytochemistry and method of preparation of commonly used medicinal plants for the management of asthma in Ethiopia. A comprehensive and systematic web-based search of full length experimental, ethno-botanical and ethno medicinal survey articles from scientific database like Pub Med, Science Direct, Web of Science and Google Scholar, were undertaken using key words: asthma, medicinal plants, ethno-botanical, herbal, phytochemistry so as to document this review article. About 23 medicinal plants like Papilionaceae, Caricaceae, Moringaceae, Liliaceae, Asteraceae etc. were found among the most common used medicinal plants in the society for the treatment of asthma. A good number of contemporary medicines have evolved from traditional medicines thus in the present circumstances, our traditional system must be given an objective and critical examination. Further research must be carried out to determine the fraction(s)/compounds that are mostly responsible for the observed anti-asthmatic activity as this will lead to drug development. As well, the potency of plants used in combination as beside being used individually should be further researched. It is recommended that further research is needed to anti-asthmatic plants and standardization of herbal formulations/preparations and to determine their side effect, efficacy, safety etc.
\end{abstract}

Keywords: asthma, ethno-botanical, herbal, medicinal plants, phytochemistry
Volume 9 Issue 3 - 2020

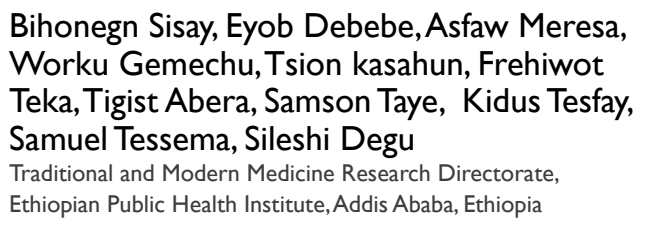

Correspondence: Bihonegn Sisay, Traditional and Modern Medicine Research Directorate, Ethiopian Public Health Institute,Addis Ababa, Ethiopia, Email bihonegnsisay@gmail.com

Received: March 13, 2020 | Published: October 30, 2020

\section{Introduction}

Asthma is a highly prevalent global disease; affecting approximately 300 million individuals' worldwide. Its evidence and severity are increasing gradually. It is associated with changes in the levels of eosinophils, mast cells, lymphocytes, cytokines and other inflammatory cell products. Asthma patients have high levels of specific IgE that binds to mast cell receptors. ${ }^{1}$ It is a rising major community health trouble worldwide, particularly in Western countries, upsetting 18.9 million adults and 8.2 million kids in the USA. ${ }^{2}$ Many studies showed a low hazard of asthma in sub Saharan countries. A worldwide predominance study on asthma and allergies in childhood indicates that prevalence rate in Ethiopia was $9.1 \%$, Kenya $15.8 \%$, Nigeria $13.0 \%$, South Africa $20.3 \%$, Algeria $8.7 \%$, Morocco $10.4 \%$, and Tunisia $11.9 \%$. The maximum prevalence was in Costa Rica 37.6, while the buck in the list was Albania 3.4\% subsequently to Indonesia $2.8 \%{ }^{3}$ Asthma prevalence in eastern Africa, including Eretria, Somalia, Kenya is predictable at $4.4 \%$, the majority of prescribers not subsequent the asthma management guidelines. If it comes to Ethiopia the prevalence rate was $9.1 \%$ as per an article published in PLOS medicine asthma in Africa, and if we approach to an area of our study in southern Ethiopia is Hawassa predictable about $4.3 \%$ for those living in 270 kilometers away from its capital city, Addis Ababa wherever it was $11.4 \%$ this may given that of industrialization. ${ }^{4}$ Medicinal plants have been used in nearly all cultures as a source of medicine. More than $85 \%$ of the population of both developed and developing countries are mainly relied on traditional medicine for their health care needs and it is unspecified that a major part of traditional therapy involves the use of plant extracts or their active principles. Due to lack of planned health care systems in developing countries, people with chronic diseases like asthma are in the middle of the most horrible suffers in their communities nowadays. Consequently, majority of the populations still have limited access or no access, mostly those in remote areas, to modern medicines. Different species of medicinal plants are used in the treatment of asthma. There are many natural herbs and herbal supplements that can be used for the treatment of asthma. Natural Asthma treatment incorporates vitamins, minerals and herbs to relieve symptoms and prevent further attack. ${ }^{5}$ Though, herbs had been priced for their medicinal, flavoring and aromatic qualities for centuries, the synthetic products of the modern age surpassed their importance. On the other hand, the blind reliance on synthetics is over and people are returning to the naturals with hope of safety and security. Over threequarters of the world population relies mostly on plants and plant extracts for health care. More than $30 \%$ of the entire plant species, at one time or other was used for medicinal purposes. It has been estimated that in developed countries such as United States, plant drugs constitute to the extent that $25 \%$ of the total drugs, though in fast developing countries such as China and India, the contribution is as much as $80 \%$. Thus, the economic importance of medicinal plants is much more to countries for instance India than to rest of the world. These countries provide two third of the plants second-hand in modern system of medicine and the health care system of rural population depend on original systems of medicine. ${ }^{6}$

Tobacco smoke, especially maternal cigarette smoking is one of the environmental Factors causing asthma which is associated to high risk of its prevalence and morbidity. Wheeze, respiratory infections and destitute air quality from traffic pollution or elevated ozone levels has also been continually associated with increased asthma 
morbidity and has an association with its development that needs further research. ${ }^{7}$ Genetic is also other factor 100 genes have been associated with asthma in at least one genetic association study. But, such studies must be repeated to ensure the findings are not because of chance. Through the end of 2005, 25 genes had been associated with asthma in six or supplementary separate populations. ${ }^{8}$ It is a chronic inflammatory condition, characterized by airway hyperresponsiveness to a diversity of stimuli largely of allergic origin with reversible air flow drawback. The most vital clinical features of asthma are wheezing, shortness of breath and cough; Symptoms occur or worsen at night, awakening the patient. ${ }^{9}$

\section{Phytochemistry and ethiobotanical information of medicenal plants that used manegment of asthma}

\section{Allium cepa linn (liliaceae), Key shinkurt(Am)}

Parts used: Bulbs

Phytochemistry: The phytochemical tests exposed that the bulbs of the plant possess alkaloids in chloroform, extract. The other constituents like flavonoids, tannins, saponin, glycosides, carbohydrates and proteins in ethanolic and aqueous extracts (Figure 1). ${ }^{10,11}$

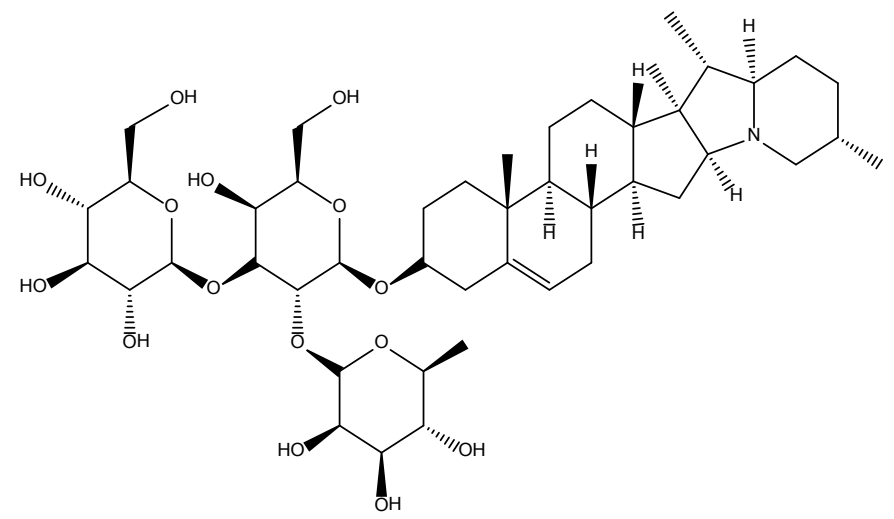<smiles>O=c1c(O)c(-c2ccc(O)c(O)c2)oc2cc(O)cc(O)c12</smiles>

\section{Quercetin}

Figure I Chemical Structures of some of the phyto-constituents isolated from Allium cepa linn.

\section{Allium sativum (Amaryllidaceae), Garlic, Nech shinkurt}

Parts used: Bulbs

Phytochemistry garlic: It contains sulfur compounds including aliin, allicin, ajoene,diallyl, trisulfide, s-allylcysteine, S-allylmercaptocystein, and, peptides, steroids, vinyldithiines, terpenoids, flavonoids, and phenols, allylpropl. In addition sulfur compounds garlic contain 17 amino acids and their glycosides, arginine and others compound. Enzymes allinase, peroxidases, myrosinase, and others amino acids and their glycosides: arginine and others Selenium, tellurium, germanium and further trace minerals, and others. Garlic also contains arginine, oligosaccharides, flavonoids, and all of which may be supportive to health. Garlic contains a highest concentration of sulfur compounds than several other Allium species (Figure 2). ${ }^{12}$ Structure of the isolated compound.<smiles>C=CCSCC(N)C(=O)O</smiles>

Aliin<smiles>C=CCSSCCCS(=O)CC=C</smiles>

Trisulfide<smiles>C=CCSCC(N)C(=O)O</smiles>

S-allylcysteine

Figure 2 Chemical Structures of some of the phyto-constituents isolated from Allium sativum.

\section{Ananas comosus, Pineapple}

Part used to: Fruit 
Phytochemistry: The secondary metabolic test for pineapple by ethanol, methanol and chroloroforms extraction is presents the following phyto chemicals. These are Terpenoids Flavonoids, Alkaloids, Saponins, Tannins, Anthraquinones, Carbohydrates, Steroids, Oils and Resins (Figure 3). ${ }^{13}$<smiles>O=C1c2ccccc2C(=O)c2ccccc21</smiles>

Anthraquinones<smiles>O=c1c(O)c(-c2ccccc2)oc2ccccc12</smiles>

Flavonoids

Figure 3 Chemical Structures of some of the phyto-constituents isolated from Ananas comosus.

\section{Carica papaya (Caricaceae), Pawpaw, Papay}

\section{Part used: Leaf}

Phytochemistry: The aqueous extract of Carica papaya exposed the presence of monosaccharides, flavonoids, steroids, reducing sugars, alkaloids, phlabotannins, free anthraquinones and glycosides whereas saponins was not detected. ${ }^{14}$

\section{Cichorium intybus L.(Asteraceae), Chicory}

Part used: Whole part

Phytochemistry: Chicoric acid has been screening as the major compound in methanolic extract of chicory. Aliphatic compounds and their derivatives comprise the main fraction while terpenoids comprise minor constituents of the plant. The flowers of chicory contain saccharides, methoxycoumarincichorine, anthocyanins, flavonoids and essentialoils, contributing to the blue colour of the perianth. The additional compounds that isolated and identified from chicory are pentadecanone, octane, $n$-nonadecane, hexadecane and also identified other volatile compound. ${ }^{15}$

\section{Cymbopogon citrates, Lemongrass, Tegesar}

\section{Part of used: Leaf}

Phytochemistry: The phytochemical analyses of Cymbopogon citrates leaves and roots performed and detected volatile oil and flavonoids in the hexane extract, while tannins, flavonoids, phenol, carbohydrates, and volatile oil were here in the chloroform extract.
In the identical revise, carbohydrates, tannins and flavonoids, were originate in the methanol extract of leaf material, at the same time as merely carbohydrates and tannins were present in the methanol extract of the roots. As well, reported that a larger comparative citral component $(86.83 \%)$ was obtained through the extraction of the essential oil with n-hexane, while compare with the extraction using other organic solvent. Essential oils that can be isolate from $\mathrm{C}$. citrates are following; Citral, Burneol, $\alpha$-terpineol, Dextro-carvone, Citronellol, ß-O-Cimene, carvomenthenone, $t$-Muurolol, Linalool, 1-Octyn-3-ol, trans-Chrysanthemal, ß-Myrcene, 3-Undecyne 3Citronellal, Neral, trans-(-)-Carveol, Geranial, Nerol, Allo-o-cimene, $\alpha$-Pinene oxide Myrcenol, Methyl- $n$-nonyl-ketone, Geranic-acid etc (Figure 4). ${ }^{16}$<smiles>C=CC(=C)CCC=C(C)CC(C)=CCC(C)=CC=O</smiles>

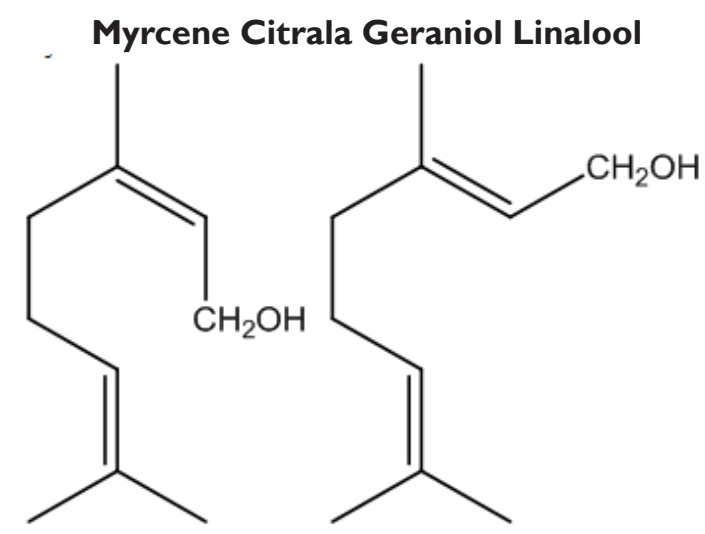

\section{Nerol Geraniol}

Figure 4 Chemical Structures of some of the phyto-constituents isolated from Cymbopogon citrates. 


\section{Euphorbia hirta, Asthma Weed,}

Parts used: Flower

Phytochemistry: The ethanol extract of flower showed the presence of alkaloid, flavanoid terpenoid, tannin and carbohydrate. The chloroform extract of the flower of Euphorbia hirta showed the presence of alkaloid, flavonoid, terpenoid, tannin and carbohydrate. The hexane extract of flower exhibited the presence of only flavanoid (Figure 5). ${ }^{17}$<smiles>O=C(O)c1cc(O)c(O)c(O)c1</smiles>

\section{Gallicacid}<smiles>O=c1cc(-c2ccc(O)cc2)oc2cc(O)cc(O)c12</smiles><smiles>O=c1c(O)c(-c2cc(O)c(O)c(O)c2)oc2cc(O)cc(O)c12</smiles>

\section{Myricitrin}

Figure 5 Chemical Structures of some of the phyto-constituents isolated from Euphorbia hirta.

\section{Lactuca taraxifolia (Asteraceae), Lettuce, Selata}

Part used: Leaf

Phytochemistry: 47 compounds was isolated from leaf methanolic extract of L. taraxacifolia, accounting for $81.45 \%$ of the total extract, and the main constituents identified were palmitic acid $(8.5 \%)$, methyl 11-octadecenoate (7.7\%), erythritol (7.5\%), glycerol (6.5\%), linolelaidic acid, methyl ester (6.2\%) and phytol (5.5\%). The chemical composition of leaf extract of L. taraxacifolia investigated in both qualitative and quantitative of the chemical constituents (Figure 6). ${ }^{18}$<smiles>OCC(O)CO</smiles><smiles>CCCCCCCCCCCCCCCC(=O)O</smiles>
palmitic acid;<smiles>C/C(=C\CO)CCC[C@H](C)CCC[C@H](C)CCCC(C)C</smiles>

Figure 6 Chemical Structures of some of the phyto-constituents isolated from lactuca taraxifolia.

\section{Moringa oleifera (Moringaceae), Moringa}

Part used: Leaves, Seed

Phyto chemistry: Phytochemical examination of extract for qualitative detection of flavonoids, alkaloids, steroid, volatile oil, tannins and saponins was performed by water and also the ethanol extracts positive however glycoside and reducing sugar negative (Figure 7). ${ }^{19}$<smiles>O=C(O)c1cc(O)c(O)c(O)c1</smiles><smiles>CCCCC(Cc1ccc(O)cc1)=[N+]([O-])[O-]</smiles><smiles>O=C(O)c1cccnc1</smiles>

Gallic acid (phenolic acid) 4-Hydroxybenzyl glucosinolate(sinalbin) Niacin 
<smiles>O=c1c(O)c(-c2cc(O)c(O)c(O)c2)oc2cc(O)cc(O)c12</smiles>

Myricetin quericetin<smiles></smiles>

Figure 7 Chemical Structures of some of the phyto-constituents isolated from Moringa oleifera

\section{Nigella sativa, black cumin}

Part used: Seeds

Phytochemistry: Phytochemical screening extracts was isolate such like solvents by ethylacetate, ptroleumether and Methanol showed major indication about the presence of secondary metabolites; Terpenoids, Alkaloids, Tannins, Phenol, Flavanoids and steroids were found to be here in Nigella sativa or Black cumin seed while saponins were not present in all solvents. These detected phytochemical compounds are known to have helpful importance medicinal in addition to physiological activities. The seeds of N. sativa hold protein, fat, carbohydrates, crude fiber. The seeds are also containing high-quality extent of various minerals and vitamins like $\mathrm{Cu}, \mathrm{Zn}$ and $\mathrm{P}$ and $\mathrm{Fe}$ etc. The seeds contain carotene which is rehabilitated by the liver to vitamin $\mathrm{A}$. The seeds in addition to contain a fatty oil rich in unsaturated fatty acids, largely linoleic acid, eicodadienoic acid, oleic acid, and dihomolinoleic acid (Figure 8). ${ }^{21}$

\section{Solanum incanum L. (Solanacea), Bitter apple, Tilik embuway}

Part used: Leaf

Phytochemistry: The preliminary phytochemical screening for the presence of alkaloids, flavonoids, tannins, phenols, saponins and proteins was carried out on the methanolic crude extracts. ${ }^{21-37}$

\section{Methods}

The ethno-botanical information was gathering from different ethno botanical publications by graduate students over the past pair of decades, the relevant ethno botanical MSC\& PHD thesis and Research as well as publications; research reports other ethno-botanical and ethno medicinal survey articles reporting in addition to databases and document record were also reviewed on asthma. Various online sources including Google Scholar, PubMed and use other search Engine were browsed using some important key terms such; medicinal plants review, and Ethno-botanical studies. The scientific names (botanic name) were checked and long-established with volumes of the plants of Ethiopia. Suitable data collection arrangement was organized to place into table scientific, family and local names of species beside with plant parts used, diseases treated and preparation of each species. The information was inserting in Excel spread and plots no plant vs part used. The collected data was analyzed using descriptive statistics to assess the frequency of different aspects such as, diversity of plants, applications and plant parts used.
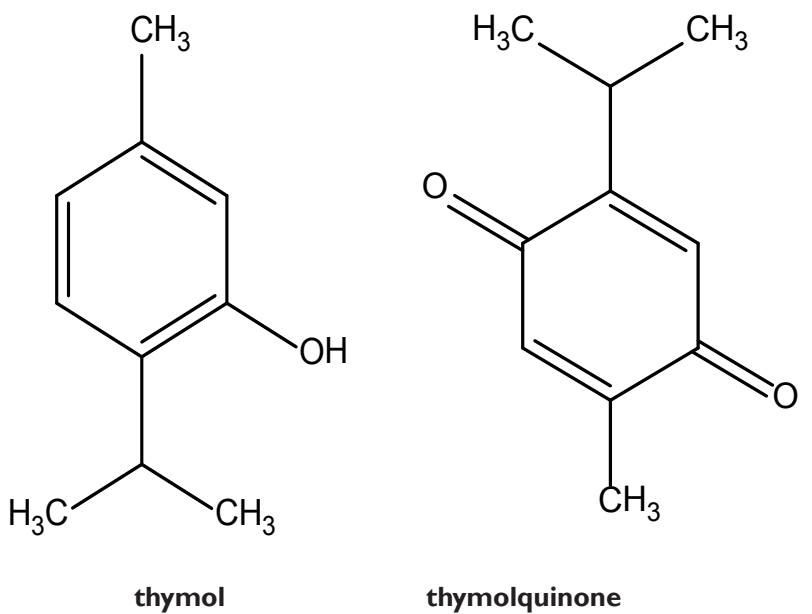

thymolquinone

Figure 8 Chemical Structures of some of the phyto-constituents isolated from Nigella sativa.

\section{Results}

Some of journals say among various disease or disorders, asthma is a severe disorder effecting large people of the world. Even though there is a significant increase in the prevalence of number of patients' pain from asthma in every age group throughout the earlier decade, the largest raise of $73 \%$ was reported by the reviewers among children and young adults below the age group of 18 years. A total of 23 medicinal plants are integrated in this review. This result is a good display for the presence of extensive variety of plant species for the treatment of Asthma. Most plants not done phytochemical investigation secondary metabolism like glycosides, sterols, Saponins, protein, Flavonoid, Coumarin by chemical and chromatographic techniques and bioactivity. From to gather the medicinal plant information some journals and thesis tells the plant family and treatment of asthma but not safety, efficacy, potent and pharmacological activity of the flora.

\section{Discussion}

From these table medicinal plants used in asthma leaf is large number used in society. These plants like Papilionaceae, Caricaceae, Moringaceae, Liliaceae, Asteraceae, Plumbaginaceae, etc. some of spices part used like stem, root, bark, bubble, fruit and flower (Figure 9) (Table 2). 


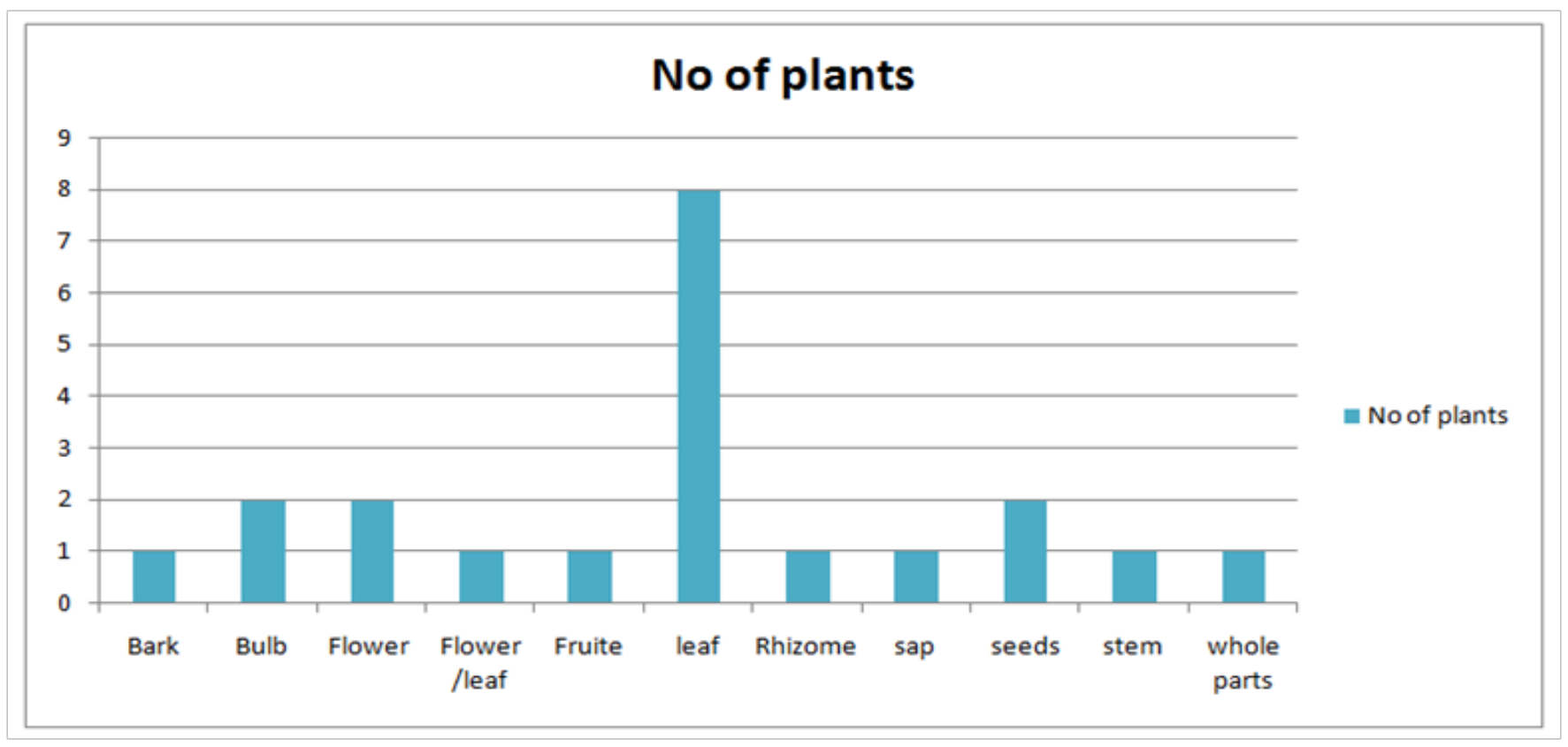

Figure 9 Use of different plant parts for the treatment of asthma.

Table I Ethnobotanical Distribution of some common medicinal plants used in the management of asthma

\begin{tabular}{|c|c|c|c|c|c|c|c|}
\hline $\mathbf{S} / \mathbf{N}$ & $\begin{array}{l}\text { Botanical names / } \\
\text { Family name }\end{array}$ & $\begin{array}{l}\text { Common } \\
\text { name }\end{array}$ & $\begin{array}{l}\text { Local } \\
\text { names }\end{array}$ & $\begin{array}{l}\text { Part (s) } \\
\text { used }\end{array}$ & Method of preparation & $\begin{array}{l}\text { Route of } \\
\text { administra- } \\
\text { tion }\end{array}$ & Reference \\
\hline I & Cymbopogon citratus & Lemongrass & Tegesar & Leaf & $\begin{array}{l}\text { Adding } 2 \text { teaspoons of dried } \\
\text { lemongrass to } 2 \text { cups of water } 1 / 2 \\
\text { teaspoon of grated ginger, } 2 \text { cloves and } \\
\text { a small piece of a cinnamon stick. Bring } \\
\text { it to a boil and then simmer for } 5 \text { to } \\
\text { 10minutes.Strain, adding a little lemon } \\
\text { juice and honey and drink it once daily } \\
\text { when suffering from asthma. }\end{array}$ & Oral & 23 \\
\hline 2 & $\begin{array}{l}\text { Carica papaya } \\
\text { (Caricaceae) }\end{array}$ & Pawpaw & Papaya & Leaf & The smoke of burnt leaf is inhaled & Oral & 24 \\
\hline 3 & Ananascomosus & Pineapple & & Fruit & Ripe fruit is eaten & Oral & 24 \\
\hline 4 & Euphorbia hirta & Asthma Weed & & Flower & $\begin{array}{l}\text { Decoction is taken orally Flower } \\
\text { Infertility in women It is prepared as } \\
\text { soup which is taken orally. }\end{array}$ & & 24 \\
\hline 5 & $\begin{array}{l}\text { Allium cepa L } \\
\text { (lliacease) }\end{array}$ & $\begin{array}{l}\text { Bulb onion, } \\
\text { common onion }\end{array}$ & $\begin{array}{l}\text { Key } \\
\text { shinkurt }\end{array}$ & Bulb & $\begin{array}{l}\text { Squeeze bulb and take one tea spoon } \\
\text { every morning }\end{array}$ & Oral & 25 \\
\hline 6 & $\begin{array}{l}\text { Allium sativum } \\
\text { L.(Amaryllidaceae) }\end{array}$ & Garlic & $\begin{array}{l}\text { Nech } \\
\text { shinkurt }\end{array}$ & Bulb & By dissolve with solvent & Oral & 26,27 \\
\hline 7 & $\begin{array}{l}\text { Aloepulcherrima M.G. } \\
\text { (Xanthorrhoeaceae) }\end{array}$ & & Seteeret & Sap & The sap is boiled with water. & Oral & 26,27 \\
\hline
\end{tabular}


Table Continued

\begin{tabular}{|c|c|c|c|c|c|c|c|}
\hline $\mathbf{S} / \mathbf{N}$ & $\begin{array}{l}\text { Botanical names / } \\
\text { Family name }\end{array}$ & $\begin{array}{l}\text { Common } \\
\text { name }\end{array}$ & $\begin{array}{l}\text { Local } \\
\text { names }\end{array}$ & $\begin{array}{l}\text { Part (s) } \\
\text { used }\end{array}$ & Method of preparation & $\begin{array}{l}\text { Route of } \\
\text { administra- } \\
\text { tion }\end{array}$ & Reference \\
\hline 8 & $\begin{array}{l}\text { Moringaoleifera } \\
\text { (Moringaceae) }\end{array}$ & $\begin{array}{l}\text { Moringa, } \\
\text { drumstick }\end{array}$ & Moringa & Leaf & Decoction is used. & Oral & 27 \\
\hline 9 & $\begin{array}{l}\text { Allium ascalonicum } \\
\text { (Liliaceae) }\end{array}$ & Shallot & & Leaf & Leaf extract is chewed & Chewed & 27 \\
\hline 10 & $\begin{array}{l}\text { Laggera } \\
\text { Crispate } \\
\text { (Asteraceae) }\end{array}$ & & Kesbedeji & Leaf & $\begin{array}{l}\text { The leaf is crushed, soaked in fresh } \\
\text { juices of its leaf then 'placed in closed } \\
\text { container for } 7 \text { days and } 3 \text { droplets are } \\
\text { given on the nose during } \\
\text { Relapsing of disease. }\end{array}$ & Oral & 28 \\
\hline II & $\begin{array}{l}\text { Pterolobiumstellatum } \\
\text { (Fabaceae) }\end{array}$ & Redwing & Kentefa & Bark & $\begin{array}{l}\text { The bark is crushed, powdered and } \\
\text { cooked with "Doro wot" then eating } \\
\text { with injera and some powders Smoked } \\
\text { like cigarette }\end{array}$ & Oral & 28 \\
\hline 12 & $\begin{array}{l}\text { PlumbagozeylanicumL.( } \\
\text { Plumbaginaceae) }\end{array}$ & & $\operatorname{Amira}(\mathrm{Am})$ & Leaf & Crushed, powdered, boiled and drink & Oral & 29,32 \\
\hline 13 & $\begin{array}{l}\text { Verbascumsinaiticum- } \\
\text { Benth. (Sclrophlara- } \\
\text { ceae) }\end{array}$ & & $\begin{array}{l}\text { Yahiajero } \\
(\mathrm{Am})\end{array}$ & Flowers & $\begin{array}{l}\text { Powdered, mixed with honey and taken } \\
\text { for } 5 \text { days }\end{array}$ & Oral & 29 \\
\hline 14 & $\begin{array}{l}\text { Withaniasomnifera (L.) } \\
\text { Dunal in Dc (Solana- } \\
\text { ceae) }\end{array}$ & Ashwagandha & $\begin{array}{l}\text { Gizawa } \\
(\mathrm{Am})\end{array}$ & Seeds & Crushed, powdered and drink & Oral & 30 \\
\hline 15 & Nigella sativa & black cumin & & Seeds & $\begin{array}{l}\text { Seeds together with Rutachalepensis } \\
\text { and garlic are pounded together, mi- } \\
\text { xed with honey and stored in sealed } \\
\text { container for few days and eaten each } \\
\text { morning. }\end{array}$ & Oral & 30 \\
\hline 16 & $\begin{array}{l}\text { Cichoriumintybus L.( } \\
\text { Asteraceae) }\end{array}$ & Chicory & & $\begin{array}{l}\text { Whole } \\
\text { plants }\end{array}$ & $\begin{array}{l}\text { Whole plants are boiled to make a } \\
\text { decoction }\end{array}$ & Oral & 31 \\
\hline 17 & $\begin{array}{l}\text { Menthalongifolia (L.) } \\
\text { Huds. (Lamiaceae) }\end{array}$ & & & $\begin{array}{l}\text { Leaves\& } \\
\text { flowers }\end{array}$ & Dried leaves and flowers heads & Oral & 31 \\
\hline 18 & $\begin{array}{l}\text { Thymus serpyllum L.( } \\
\text { Lamiaceae) }\end{array}$ & $\begin{array}{l}\text { Breckland } \\
\text { thyme }\end{array}$ & Tosgn & Leaves & Dried leaves & Oral & 31 \\
\hline 19 & $\begin{array}{l}\text { Solanumincanum L. } \\
\text { (Solanacea) }\end{array}$ & Bitter Apple & $\begin{array}{l}\text { Tilikem- } \\
\text { buway }\end{array}$ & Seed & $\begin{array}{l}\text { Powder mixed with water and filtrate } \\
\text { taken }\end{array}$ & Oral & 31 \\
\hline 20 & $\begin{array}{l}\text { Croton macrostachyus } \\
\text { De (Euphorbiaceae) }\end{array}$ & $\begin{array}{l}\text { Broad-Leaved } \\
\text { Croton }\end{array}$ & $\begin{array}{l}\text { Mesana } \\
\text { (halaba } \\
\text { name) }\end{array}$ & Stem & $\begin{array}{l}\text { Dry stem is crushed, powdered, mixed } \\
\text { with Hageniaabyssinica powder added } \\
\text { to boiled coffee drunk. Tip of leaf is } \\
\text { squeezed the liquid is applied to the } \\
\text { area. Inserting the tip(bud) of the leaf } \\
\text { in the nose for } 2 \text { hours or cooking } \\
\text { the tip(bud) leafs with coffee leaf and } \\
\text { drunk }\end{array}$ & Oral & 33 \\
\hline 21 & $\begin{array}{l}\text { Lactucataraxifolia(Aste- } \\
\text { raceae) }\end{array}$ & Lettuce & Selata & Leaf & Decoction is taken oral & Oral & 34 \\
\hline 22 & $\begin{array}{l}\text { Zingiberofficinale } \\
\text { (Zingiberaceae) }\end{array}$ & Ginger & Zingebel & Rhizome & $\begin{array}{l}\text { The stem is chewed and the juice } \\
\text { extracted }\end{array}$ & Oral & 34 \\
\hline 23 & $\begin{array}{l}\text { Ipomoea batatas } \\
\text { (Convolvulaceae) }\end{array}$ & Sweet potato & Sikuardinch & $\begin{array}{l}\text { Leaves, } \\
\text { tuber }\end{array}$ & $\begin{array}{l}\text { Leaves The leaves squeezed in cold } \\
\text { water sieved and drunk, first in the } \\
\text { morning and last in the evening }\end{array}$ & Oral & 34 \\
\hline
\end{tabular}


Table 2 medicinal plants parts used in management of asthma

\begin{tabular}{ll}
\hline Plants that part used & No of plants \\
\hline Bark & $\mathrm{I}$ \\
Bulb & 2 \\
Flower & 2 \\
Flower /leaf & $\mathrm{I}$ \\
Fruit & $\mathrm{I}$ \\
Leaf & 8 \\
Rhizome & $\mathrm{I}$ \\
Sap & $\mathrm{I}$ \\
Seeds & 2 \\
Stem & $\mathrm{I}$ \\
whole parts & $\mathrm{I}$ \\
\hline
\end{tabular}

\section{Conclusion}

Asthma is a worldwide problem. Several synthetic drugs are used to carefor acute symptoms of astma, but they are not finallysafe for long term use. Therefore trytofind has been started once again to look back to traditional medicine which can be used to management of asthma. Medicinal plants are mostly an important basis of drug, surly many of the presently available medicine. In the history decade, research has been pay attention scientific assessment of herbal medicine of plants source for management of many diseases. The developing country 80 percent of peoples are using medicinal plants as treatment of health problem, Like Ethiopia. It used for asthma should not be used in the case of mediator or severe asthma affected, however they are always very effective in prevent other ways the patient care by physician. In most of journal and thesis has no defining the toxic effect, side affected and adversely effect of the medicinal plants. In this review gather ethno-botanical information about medicinal plants but, additional research is needed for the assessment of the safety, efficacy and quality of those medicinal plants utilized for the treatments of asthma. In addition to these Literature and systematic work is recently required in the field of medicinal plants regarding evaluation of heavy metals and presence of aflatoxins etc to call them safe medicinal plants and quantitatively analysis of phytochemistry.

\section{Acknowledgements}

None.

\section{Conflicts of interest}

Author declares that there are no conflicts of interest.

\section{References}

1. Choudhry S, Seibold MA, Borrell LN, et al. Dissecting complex diseases in complex populations: asthma in Latino Americans. Proceedings of the American Thoracic Society. 2007;4(3):226-233.

2. Taur DJ, Patil RY. Some medicinal plants with antiasthmatic potential: a current status. Asian Pacific journal of tropical biomedicine. 2011;1(5):413-418.
3. Tefereedgn EY, AM Ayana. Prevalence of asthma and its association with daily habits in Jimma Town, Ethiopia. Open J Asthma. 2018:2(1):11-17.

4. Dalo Admasu, Raghavendra Yarlagadda, Ramanjireddy Tatiparthi. Assessment of asthma treatment outcomes among adult outpatients at Nemmh Chest Clinic in Hadiya Zone, Southern Ethiopia. Journal of Basic and Clinical Pharmacy. 2017;8(3).

5. Prasad Ranjeeta, Rahul Dev Lawania, Rajiv Gupta. Role of herbs in the management of asthma. Pharmacognosy Reviews. 2009;3(6):247.

6. Kumar S, Agnihotri VK, Thakur S, et al. Some important medicinal plants used in the treatment of asthma-a review. Int J Pharma Sci Res. 2012;3(10):500-502.

7. Ober C, Hoffjan S. Asthma genetics 2006: the long and winding road to gene discovery. Genes and immunity. 2006;7(2):95.

8. Panthong A, Kanjanapothi D, Taylor WC. Ethno botanical review of medicinal plants from Thai traditional books, Part I: Plants with antiinflammatory, anti-asthmatic and antihypertensive properties. Journal of Ethno pharmacology. 1986;18(3):213-228.

9. Jayaprakasam B, Yang N, Wen MC, et al. Constituents of the antiasthma herbal formula ASHMITM synergistically inhibit IL -4 and IL -5 secretion by murine Th2 memory cells, and eotaxin by human lung fibroblasts in vitro. Journal of integrative medicine. 2013;11(3):195205 .

10. Clarke R, Lundy FT, McGarvey L. Herbal treatment in asthma and COPD-current evidence. Clinical Phytoscience. 2015;1(1):4.

11. Shenoy C, Patil MB, Kumar R, et al. Preliminary phytochemical investigation wound healing activity of Allium cepa Linn (Liliaceae). International Journal of Pharmacy and Pharmaceutical Sciences. 2009;2(2):167-175.

12. Pareek Sunil. Onion (Allium cepa L.)." Fruit and Vegetable Phytochemicals: Chemistry and Human Health. $2^{\text {nd }}$ edn. Yahia, EM editor. 2017. p. 1145-1161.

13. Tesfaye A, Mangesha W. Traditional Uses, Phytochemistry and Pharmacological Properties of Garlic (Allium Sativum) and its Biological Active Compounds. International Journal of Scientific Research, Engineering and Technology. 2015;1(5):142-148.

14. Vijayanand S, Sanjana T. Phytochemical Studies of Phyllanthusemblica, Ananascomosus, Momordicacharantia Extracts. Int $J$ Pharma Res Health Sci. 2017;5(4):1810-15.

15. Biu AA, Buratai LB, Ahmed AA, et al. Phytochemistry, toxicity and efficacy of crude aqueous extract of carica papaya leaf against trypanosomabrucei. Bangladesh Journal of Veterinary Medicine. 2016;14(1):99-102.

16. Street RA, Sidana J, Prinsloo G. Cichoriumintybus: Traditional uses, phytochemistry, pharmacology, and toxicology. Evidence-Based Complementary and Alternative Medicine. 2013.

17. Ekpenyong CE, Akpan EE, Daniel NE. Phytochemical Constituents, Therapeutic Applications and Toxicological Profile of Cymbopogon citratus Stapf (DC) Leaf Extract. Journal of Pharmacognosy and Phytochemistry. 2014;3(1):133-141.

18. Ahmad W, Singh S, Kumar S. Phytochemical screening and antimicrobial study of Euphorbia hirta extracts. $J$ Med Plants Stud. 2017;5:183-186.

19. Ololade ZS, Kuyooro SE, Ogunmola OO, et al. Phytochemical, Antioxidant, Anti-Arthritic, Anti-Inflammatory and Bactericidal 
Potentials of the Leaf Extract of Lactucateraxacifolia. Global Journal of Medical Research. 2017.

20. Patel P, Patel N, Patel D, et al. Phytochemical analysis and antifungal activity of Moringaoleifera. International Journal of Pharmacy and Pharmaceutical Sciences. 2014;6(5):144-147.

21. Yessuf AM. Phytochemical extraction and screening of bio active compounds from black cumin (Nigella Sativa) seeds extract. Am J Life Sci. 2005;3:358-364

22. Boskabady, Mohammad Hossein, et al. The possible prophylactic effect of Nigella sativa seed extract in asthmatic patients. Fundamental \& clinical pharmacology. 2007;21(5):559-566

23. Mega TP, Santos PDM, Souza-Machado A, et al. Use of medicinal herbs by patients with severe asthma managed at a Referral Center. Brazilian Journal of Pharmaceutical Sciences. 2011;47(3):643-649.

24. Madike LN, Takaidza S, Pillay M. Preliminary phytochemical screening of crude extracts from the leaves, stems, and roots of Tulbaghiaviolacea. Int $J$ PharmacognPhytochem Res. 2017;9(10):1300-1308.

25. Okoli RI, Aigbe O, Ohaju-Obodo JO, et al. Medicinal herbs used for managing some common ailments among Esan people of Edo State, Nigeria. Pakistan Journal of Nutrition. 2007;6(5):490-496.

26. Getaneh S, Girma Z. An ethno botanical study of medicinal plants in DebreLibanosWereda, Central Ethiopia. African Journal of Plant Science. 2014;8(7):366-379.

27. d'Avigdor E, Wohlmuth H, Asfaw Z, et al. The current status of knowledge of herbal medicine and medicinal plants in Fiche, Ethiopia. Journal of Ethno biology and Ethno medicine. 2014;10(1):38.

28. Sonibare MA, ZO Gbile. Ethno botanical survey of anti-asthmatic plants in South Western Nigeria. African Journal of Traditional, Complementary and Alternative Medicines. 2008;5(8):340-345.
29. Gebeyehu G. An ethno botanical study of traditional use of medicinal plants and their conservation status in MechaWereda, West Gojam Zone of Amhara Region, Ethiopia. MScThesis; 2011. 2016.

30. Regassa R. Assessment of indigenous knowledge of medicinal plant practice and mode of service delivery in Hawassa city, southern Ethiopia. Journal of Medicinal Plants Research. 2013;7(9):517-535.

31. Kassa, Zewdie, ZemedeAsfaw, et al. Ethno botanical study of medicinal plants used by the local people in Tulu Korma and its surrounding areas of Ejere district, Western Shewa zone of Oromia regional state, Ethiopia. Journal of Medicinal Plants Studies. 2016;4(2):24-47.

32. Qureshi RA, Ghufran MA, Sultana KN, et al. Ethnomedicinal studies of medicinal plants of Gilgit District and surrounding areas. Ethnobotany Research and Applications. 2010;5:115-122.

33. Birhanu Z, Endale A, Shewamene Z. An ethno medicinal investigation of plants used by traditional healers of Gondar town, North-Western Ethiopia. Journal of medicinal plants studies. 2015;3(2):36-43.

34. Regassa R, Bekele T, Megersa M. Ethno botanical study of traditional medicinal plants used to treat human ailments by Halaba people, southern Ethiopia. Journal of Medicinal Plants Studies. 2017;5(4);3647

35. Panthong A, Kanjanapothi D, Taylor WC. Ethno botanical review of medicinal plants from Thai traditional books, Part I: Plants with antiinflammatory, anti-asthmatic and antihypertensive properties. Journal of Ethno pharmacology. 1986;18(3):213-228.

36. Prasad R, Lawania RD, Gupta R. Role of herbs in the management of asthma. Pharmacognosy Reviews. 2009;3(6):247.

37. Ismail MYM. Antiasthmatic herbal drugs-a review. International Journal of Pharmacy and Pharmaceutical Sciences. 2010;2(3):28-29. 